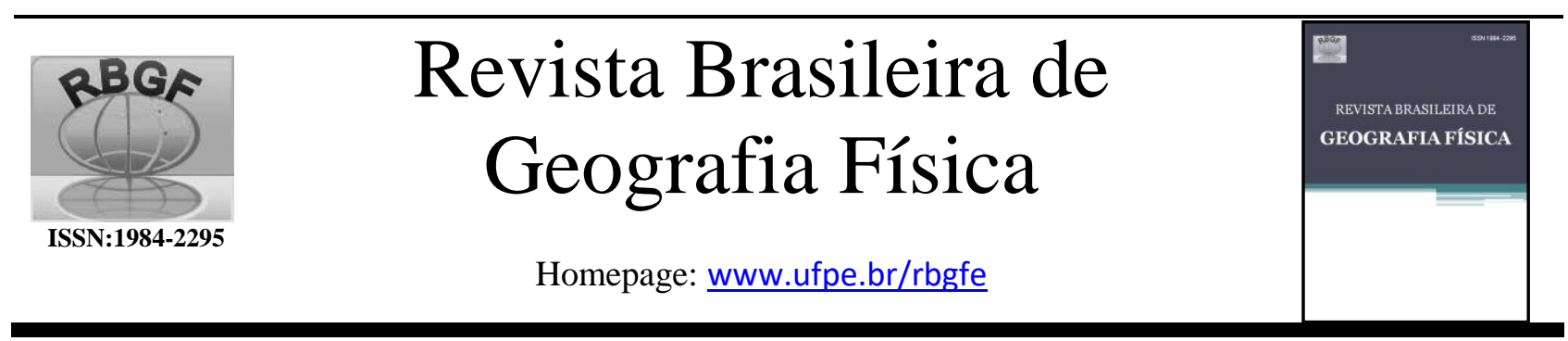

\title{
Application of RapidEye high-resolution satellite images to population resilience analysis along on the banks of the Una River, Palmares, Pernambuco, Brazil
}

\author{
Betânia Queiroz da Silva ${ }^{1}$, Luciana Maria da Silva², Carlos Alberto Borba Schuler ${ }^{3}$
}

${ }^{1}$ Discente de doutorado do Programa de Pós-Graduação em Engenharia Civil, Bolsista CAPES. Universidade Federal de Pernambuco (UFPE), Recife - PE. Rua Venezuela, 24, Jaboatão dos Guararapes - PE, bethqueiroz@ gmail.com (autor correspondente) ${ }^{2}$ Pesquisadora no Centro de Estudos de Petróleo. Universidade de Campinas (UNICAMP), Campinas SP. lumasilva15@gmail.com. ${ }^{3}$ Docente do Programa de Pós-Graduação em Ciências Geodésicas e Tecnologias da Geoinformação. Universidade Federal de Pernambuco (UFPE), Recife - PE. cschuler@ufpe.br.

Artigo recebido em 13/11/2017 e aceito em 30/05/2018

\begin{abstract}
A B S T R A C T
In 2010, Palmares city, located in the state of Pernambuco, suffered an extensive environmental impact due to a strong flood of the Una River, with major repercussions for resident population. This work presents a post-flood socio environmental situation, due to this event being considered of high magnitude. For this was used the RapidEye spatial high-resolution satellite image of year 2015 to check the occupation of the area, contrasted with on-site visit and the data of Floods Susceptibility Maps belonging to Geological Survey of Brazil - (in Portuguese CPRM), which enabled us identify the area classification as of high, medium and low risk. In this context stand out that interventions had been taken by the government to combat and minimize new flood due the risk area for the population. The development Floods Susceptibility Maps and Digital Terrain Models (DTM) are necessary to forecasting of risk for this were used. From the analyzes it was evidenced that the population continues to occupying many affected areas by floods and that even with the public projects development to combat the floods, the region is still very vulnerable. Therefore, the affected areas monitoring is a substantial factor to detect the impacts and to forestall the future risks. It is noteworthy that all products were generated from the high-resolution image data, which allow a better interpretation of area and improve in the projects restructuring.
\end{abstract}

Keywords: remote sensing, floods susceptibility maps, hydric resource, environment.

\section{Aplicação de imagens de satélite de alta resolução RapidEye para análise da resiliência da população as margens do Rio Una, Palmares - PE, Brasil}

\section{R E S U M O}

Em 2010, a cidade de Palmares localizada no estado de Pernambuco, sofreu um intenso impacto ambiental devido a forte enchente do Rio Una, com maiores repercussões para população residente nas margens do rio. Este trabalho apresenta uma situação socioambiental pós-enchente, devido este evento ser considerado de alta magnitude. Para isto, foi utilizado imagens de satélite de alta resolução RapidEye de 2015 para que se pudesse analisar a ocupação da área e realizar uma comparação com informações obtidas em campo e com os dados obtidos da Carta de Susceptibilidade à inundação desenvolvida pelo Serviço Geológico do Brasil (CPRM), a qual nos permitiu identificar a classificação da área de risco como: alto, médio e baixo. Neste contexto, destaca-se que intervenções têm sido realizadas pelo governo para combater e minimizar novas inundações, isto se deve ao fato que a área apresenta risco a população. O desenvolvimento de Carta de Suscetibilidade a Inundações e Modelos Digitais do Terreno (MDT) são necessários para predição do risco, por isto foram utilizadas. Pela análise de todas as informações foi evidenciando que a população continua ocupando as áreas que foram afetadas pelas inundações e que mesmo com os projetos públicos desenvolvidos para combater as inundações, a região ainda é muito vulnerável. No entanto, o monitoramento das áreas afetadas é um fator substancial para detectar os impactos e realizar predições aos riscos que podem acontecer ao longo do tempo. Vale destacar que todos os produtos gerados foram a partir de imagens de alta resolução, a qual permite uma melhor interpretação da área e melhora a reestruturação de projetos.

Palavras chaves: sensoriamento remoto, carta de suscetibilidade à inundação, recurso hídrico, meio ambiente.

Silva, B. Q., Silva, L. M., Schuler, C. A. B. 


\section{Introduction}

Cities are an inseparable part of the contemporary living way it is the world occupation mode (Araujo 2010). Approach about the city is the same as addressing the urban life process and its daily challenges (Oliveira 2015). In this context, it stand out that from the 1950s, it is verified in Brazil an accelerated growth of the urban areas, causing a disorderly urbanization process in these areas and a lot of socio-environmental problems for the population living in the area and close to the area. With that, the socio-spatial segregation on cities was accentuated (IBGE 2000; Reckiegel and Robaina 2005). This process causes problems due to the lack of infrastructure in the cities upon receiving large numbers of people and new social demands (Sánchez 2010).

Brazil has an extremely urban population with approximately $84.3 \%$ living in the city's urban area, to according census data IBGE (2010). Being a country that presents great difficulties due to this centrality of the population on city, and the lack of planning of this growth causes various social and environmental problems (Novack and Kux 2010) and challenges that only tend to increase. As a consequence, natural disasters are presented as one of the great challenges arising from this city growth of disorderly way, caused: traffic congestion, accumulation of garbage, air pollution, floods (Amaral and Ribeiro 2009), accelerated erosion and sliding (Tominaga 2009 and Tominaga et al. 2015), lack of water or space, irregular occupations that are subnormal settlements, these are generally occupied by the low-income population that live in areas frequently of environmental protection (Gonçalves et al. 2013) or, areas subject to geological risk (Reckiegel and Robaina 2005; Santos et al. 2016), as like as, the increase of neighborhoods with poor infrastructure, located housing in risk areas and changes in the natural systems (Bandeira and Coutinho 2008).

It is also important to highlight the natural phenomena related to weather, especially when extreme events occur, which bring social and economic consequences to the population living in risk areas, negatively impacting the population life's quality over time. In Brazil, over the past decades, has experienced significant advances in relation to environmental risk management, driven by the mass and flood movements that occur in almost all major Brazilian cities (Bandeira et al. 2009). These movements involve loss property and infrastructure, and casualties.
At Zona da Mata South of the State of Pernambuco, extreme rainfall events are observed in the autumn-winter period, with events occurrence of high magnitude and recurrence in months June and July. Although these extreme events trigger geomorphological processes on the slopes and watershed, such as acceleration of linear erosion and mass movements, the floods and flood constitute the main geomorphological risk, which affects the region's population comprehensively, standing out as repeatedly affected area by such events, such as the Una River Basin (Girão et al. 2013).

In the city of Palmares the floods are recurrent; in 2010 a major flooding happened. Eleven months later, the city suffered with the rains and decreed state of public calamity, again. Rainfall dysrhythmias cause significant impacts to a population, especially in areas where anthropogenic action contributes to the potentiation of natural disasters (Oliveira, 2013). It is evidenced that without effective action, the resident population in the floodplain of the Una River, in the Palmares city, is in danger situation, with the imminence of new floods that can be as striking as the extreme events with rains records in the years $1200 \mathrm{~mm}$ (2010), 209mm (2011) and $114 \mathrm{~mm}$ (2017).

Resilient cities have been defined from the degree to which cities are able to tolerate changes, reorganizing around a new set of structures and processes, simultaneously balancing the ecosystems functions (Oliveira, 2015). According to Cunico and Oka-Fiori (2014) study of resilience and adaptation are essential to understand the way as the people and places resist the danger, adjusting your behavior, especially during and immediately after the event. Therefore the objective of this study is to analyze the population's resilience on the banks of the Una River through RapidEye highresolution satellite images, 04-17-2015, from of the flood risk mapping conducted by Geological Survey of Brazil - (In Portuguese CPRM), on-site visit in August 2015 and April 2017 for the ratification of data and of the interferences of public projects to deal with events of major magnitude of flooding suffered by population of the Palmares city.

\section{Characterizing of Study Area}

The developed reports by ITEP (2011) provide a historic of recurrent extreme events of flood in the Palmares city in the years 1973, 1975, 1988, 2000, 2005 and 2010, which show that rains 
caused great damage, declare a state of public calamity with an emergency situation. In addition, there are new events of high rainfall and major consequences for the population in 2011 and 2017.

The Palmares city belongs to the Mata Mesoregion and the Southern Mata Microregion of the state of Pernambuco. It is inserted in the Borborema Province with lithostratigraphic units of the Neoproterozoic and Mesoproterozoic. The area is under the dominance of the Zona da Mata South hills, with weather As' (hot and humid) with autumn-winter rains which causes a rainfall above $1,800 \mathrm{~mm}$ annually, with the Una River being the most important in the Mata region. Fig. A.1 shows the Palmares city location map in the state of Pernambuco. It should be emphasized that this work focuses in the area on the banks of the Una River, where the urban area of the city is located, as can be seen in the satellite image in Figure 1.

This city is characterized by a relief that is part of the reworked surfaces unit that is formed by areas that have undergone intense reworking with heavily dissected relief and deep valleys. The region is formed by the "hills sea" that precedes the Chapada da Borborema and poor soils. The city is located in the Una River middle course that presents the pluviometric regime with occurrence of a humid period between April and August, being generally the months of June and July which the major rainfall records occur (SNIRH, 2016).

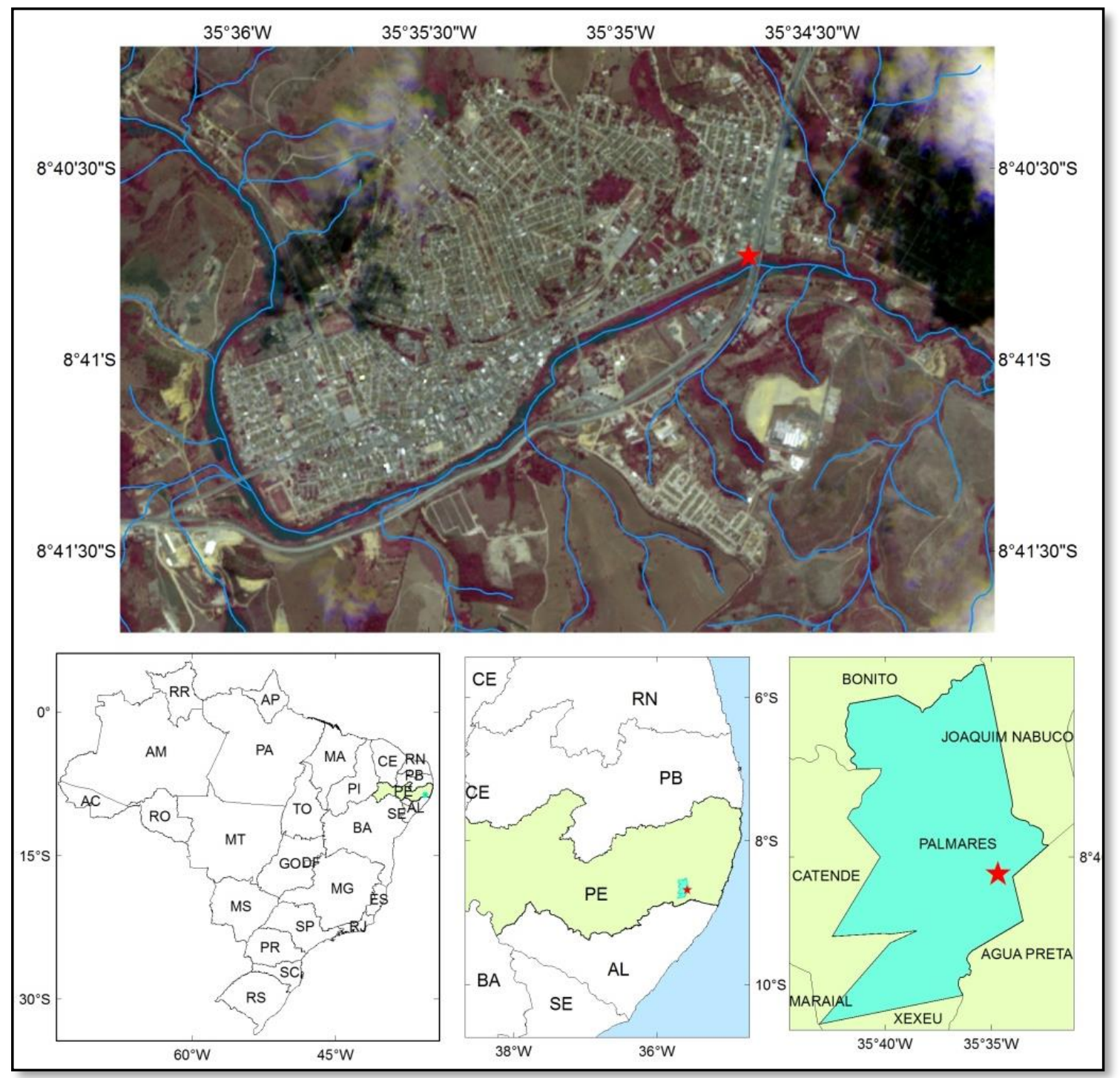

Figure 1: Location Map of study area in Palmares - PE.

Una River, in the Palmares city, presents a wide diversity of water use, including public supply, leisure, irrigation for family agriculture and livestock. In the city the sulcro-alcohol activity has 
great emphasis with North - South Plant and this segment presents significant water consumption, but it has polluting potential. The fishing activity in the Palmares city is not very expressive, carried out only for domestic consumption. Domestic effluents are discharged directly into river, increasing pollution.

The interfluvial domain is characterized by flat hills, where there are few portions of native forest in the tops, due to the planting of sugar cane, as well as the housing on its slopes. While in the fluvial domain, which despite the good trough is found with great concentration of aquatic plants (baronesas), planting of sustenance grasses and remnants of old beams of homes, in other words, with apparent signs of abandonment, as shown in Figure 2.

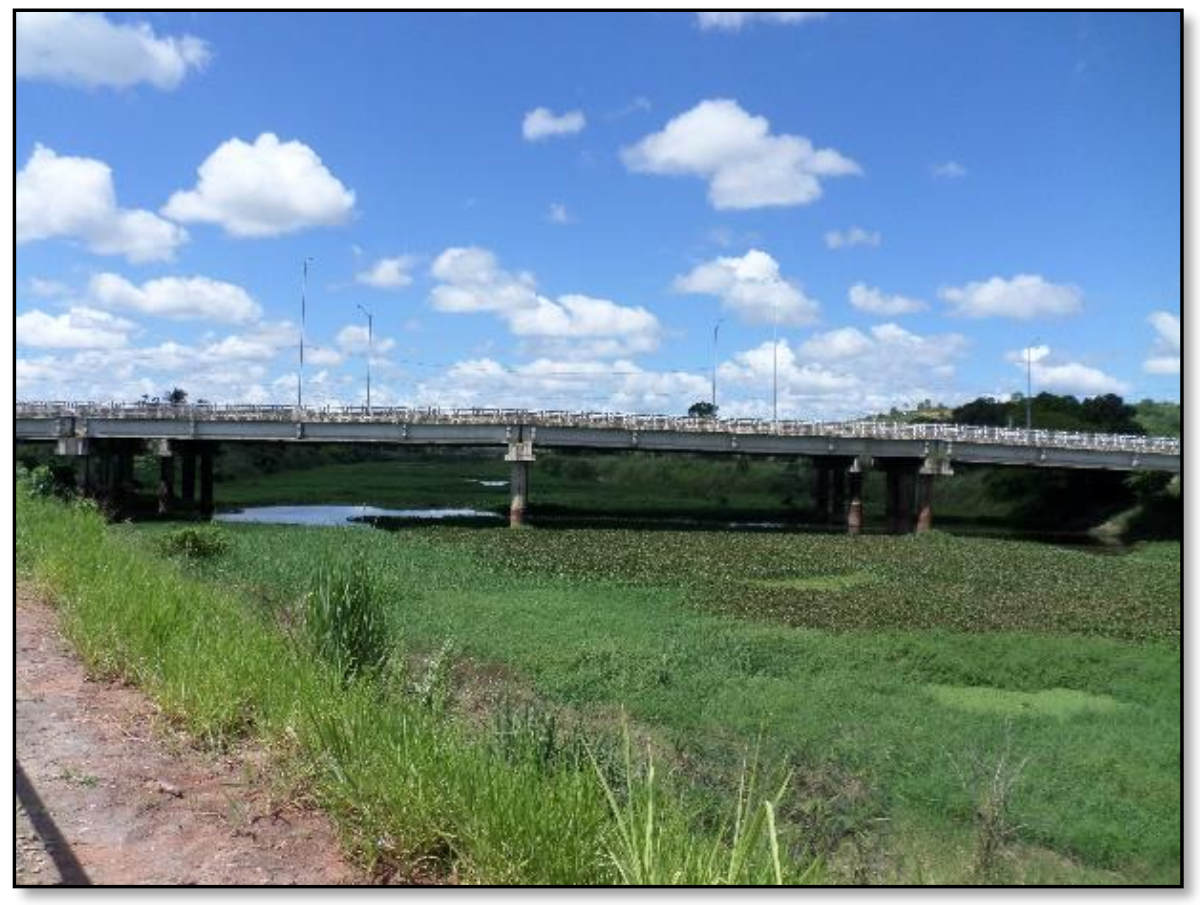

Figure 2: Banks of the Una River, view of the Bridge over the BR-101. Source: The authors (2017).

\section{Materials and methods}

An on-site visit was carried out on August 4, 2015, where the urban area was observed along on the banks of the Una River, located in the Palmares city, which the last floods devastated, to verify the current situation, in relation to recovery of the area and population's adaptation to their risk situation. In April 2017, a review was made to verify the conclusion of structural works (relocation of the local population, boardwalk completion on the riverbanks) and non-structural (monitoring and awareness of the riverside population).

The images from the RapidEye satellite (resolution 5.0 m) obtained on April 17, 2015 were used for interpretations of the occupied areas on the riverbanks, available and obtained free of charge in the Geocatálogo of Ministry of Environment (MMA, 2016), whose main characteristics are presented in Table 1. For the total overlay of the study area, the images 2535103_2015_04_17_RE2_3A_318218_CR were used, with the composition of the bands 4,3 , 2 for a better interpretation of the information obtained in the field.

Geographic Information System (GIS) data, cartographic base, geomorphological map, Digital Terrain Models (DTM) originating of CPRM mapping in 2014 were used. These products are generated with a scale of 1: 25,000, which aim to map areas susceptible to flood and mass gravitational movements, classified as high, medium and low risk, mainly related to mass movements and flooding in Brazilian city prioritized by the Federal Government (CPRM, 2016). In view of all the information collected, it is possible to show the risk in which the area is exposed. The data were inserted into the ArcGis ${ }^{\circledR}$ software for the comparison and analysis of RapidEye images with the data of Susceptibility 
Maps of Gravitational Mass Movements and Floods, to verify which level the flood defined by CPRM the area occupied by the population is classified.

Table 1. Features of RapidEye Image Satellites. Source: Adapted from RapidEye (2016)

\begin{tabular}{ccccc}
\hline System & $\begin{array}{c}\text { Height } \\
(\mathbf{k m})\end{array}$ & $\begin{array}{c}\text { Time Resolution } \\
\text { (days) }\end{array}$ & $\begin{array}{c}\text { Spectral resolution by } \\
\text { bands }(\mathbf{n m})\end{array}$ & $\begin{array}{c}\text { Pixel size - } \\
\text { orthorectification (m) }\end{array}$ \\
\hline RapidEye & 630 & 5,5 days (at & Blue $-440-510 \mathrm{~nm}$ & $5 \mathrm{~m}$ \\
& & nadir) & Green $-520-590 \mathrm{~nm}$ & $5 \mathrm{~m}$ \\
& & Red $-630-685 \mathrm{~nm}$ & $5 \mathrm{~m}$ \\
& & Red Edge $-690-730 \mathrm{~nm}$ & $5 \mathrm{~m}$ \\
& & NIR $-760-850 \mathrm{~nm}$ & $5 \mathrm{~m}$ \\
\hline
\end{tabular}

Oliveira (2015) presented a diagram that describes the discourse analysis, in Palmares city, disclosing that articulatory practices have as main focuses: Governance and Knowledge. These focuses offer conflicts as well as they are directly related. Governance is structured on the basis of Organization, Budget, Natural Resources Management and Answer; while the Knowledge structuring is given by Ability to Learn, Understand Risks, Education and Information. These aspects are important in what is assigned Urban Resilience Aroused, because it is the set of factors provoked or aroused by the disasters that occurred in the city that contribute to urban resilience, as shown to briefly in Figure 3.

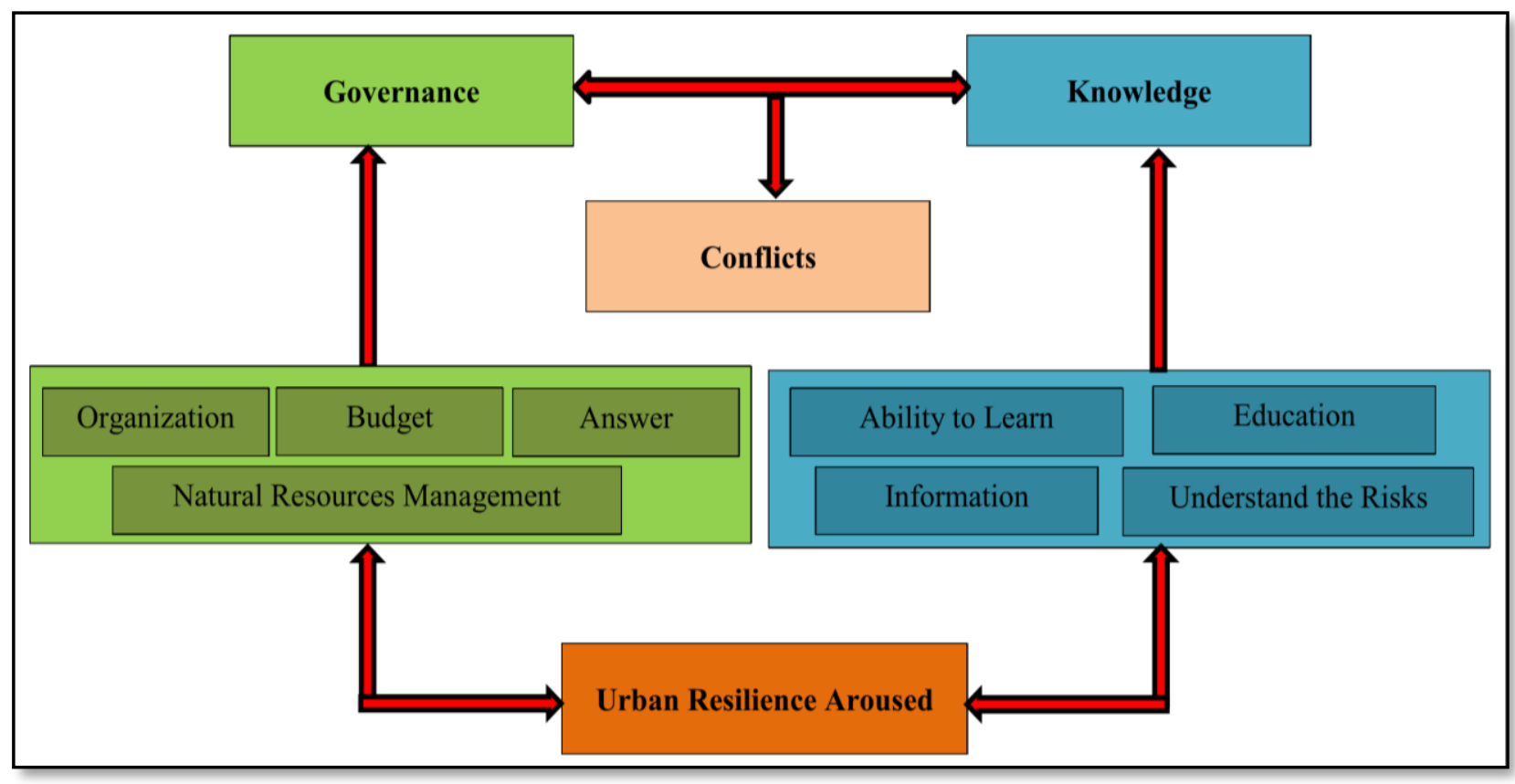

Figure 3: Flow Chart of relations in urban resilience discourse. Source: Adapted from Oliveira (2015).

\section{. Results and Discussion}

It was evidenced with the on-site visit that the bridge built in 2010, in other words, the duplication of the BR-101, after the flood, at the location of $-8.678778 \mathrm{~S}$ and $-35.577722 \mathrm{~W}$, height of $118 \mathrm{~m}$, was a planned reconstruction, however is not being kept. On the banks of the Una River was constructed an edge with jogging track as shown in Figure 4. 


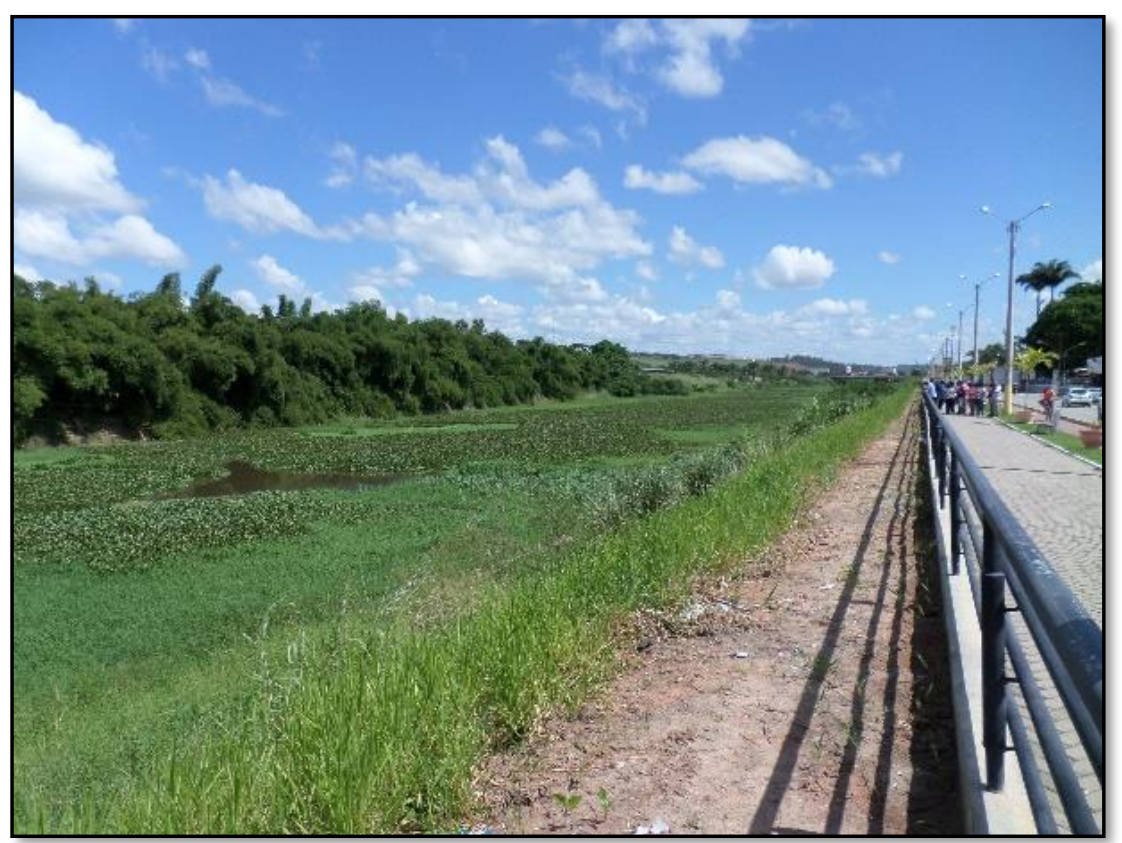

Figure 4: Banks of the Una River, view of the sidewalk. Source: The authors (2017).

The river edge construction project avoids new occupations by the population on the river banks, avoiding to vulnerability and possible damages in new floods. In the margins stands out the sustentation grasses planting, contrasting with an asphalt corridor for pedestrian (Figure 5).
However, only in the city central area, the project is completed. In the east and west stretches of Una River was not executed the project, yet. Even the edge construction had been in the initial project, there is not great progress in the works.

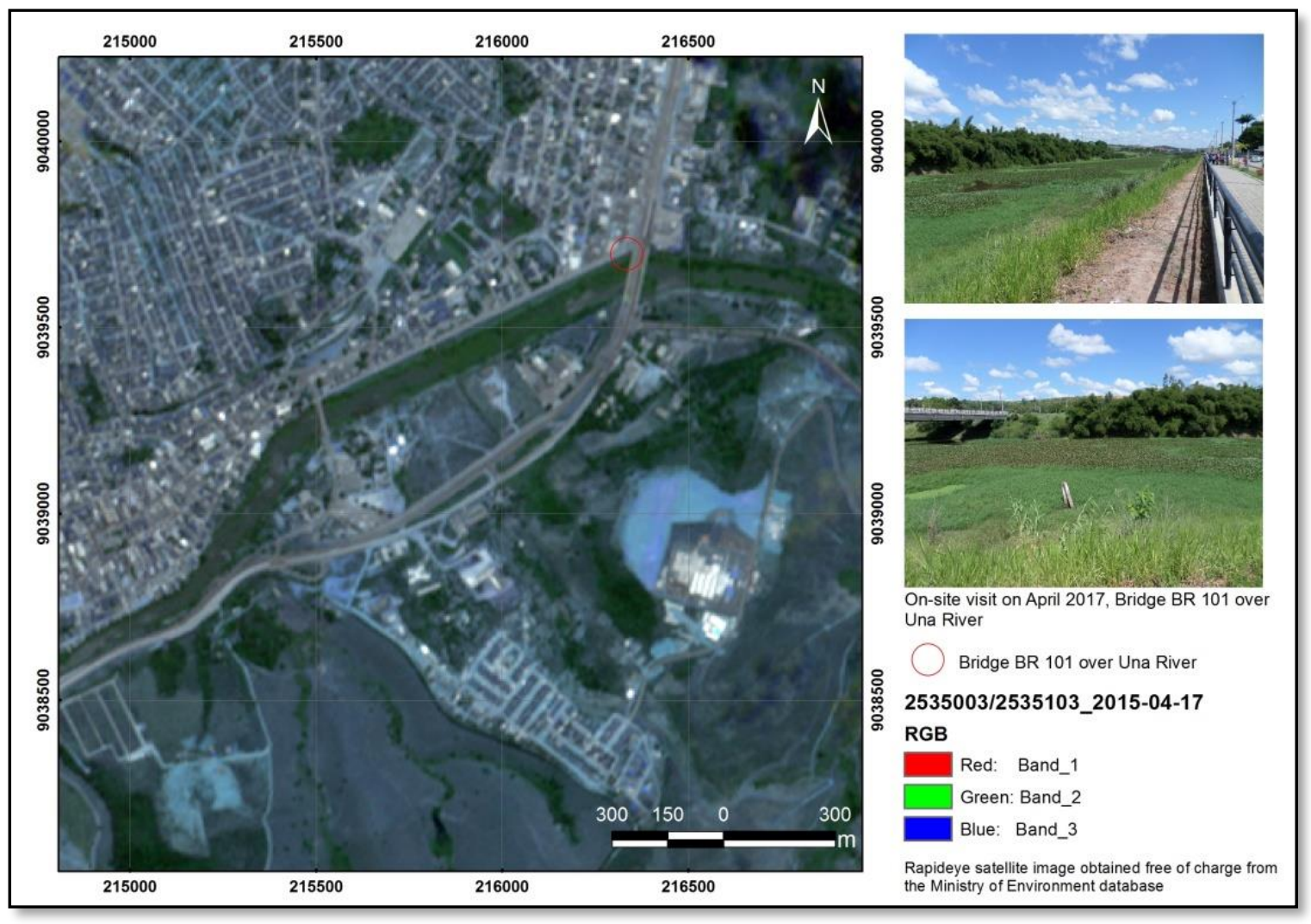

Figure 5: Map of the area visited in 2017, with emphasis on the construction of the bridge and the jogging 
track and sustentation grasses planting

In April 2017 it was verified that the work is without maintenance and new irregular homes are already inserted near the area and the River edge is with urban waste that can obstruct the water flow in case of high rainfall. Following the river course, towards the downstream, in the city center was verified that the homes reconstruction follows by the population, because the works of revitalization and construction of the edge are stopped and it did not contemplate the reached whole area by the floods as predicted the initial project, as shown in Figures 6(a) and 6(b).

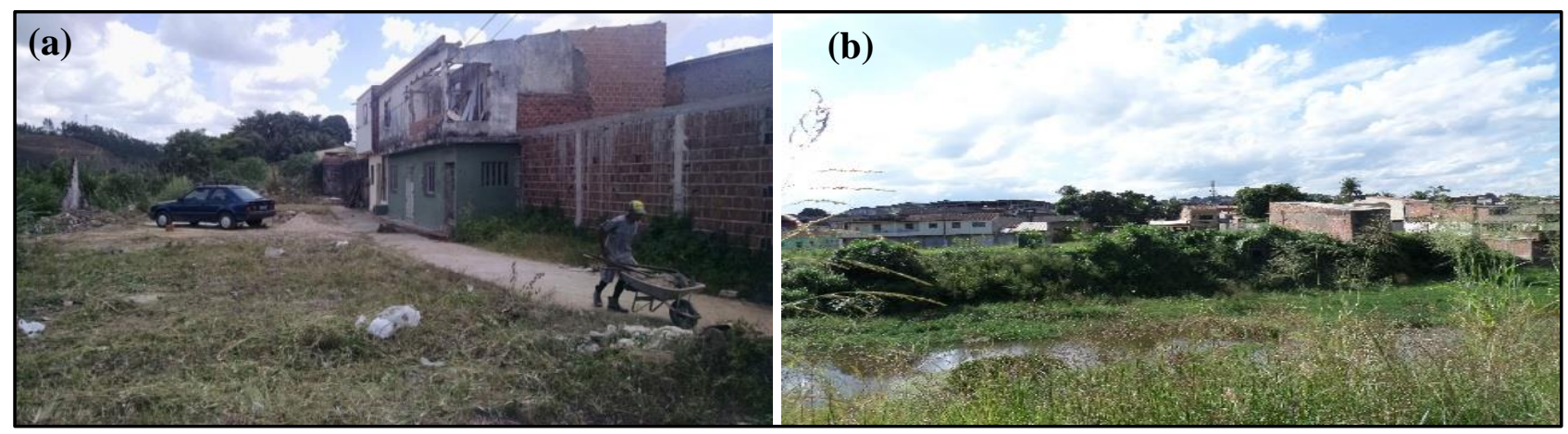

Figure: 6(a) and A.6(b). Place where the revitalization project was not implemented, irregular constructions made by local residents; 6(a) in 2015 and 6(b) in 2017. Photo Source: 6(a) Silva et al. (2017) and 6(b) The authors (2017)

It is noteworthy that part of the population of the area was compensated because they lost everything with the flood of 2010 , others received a house in the village constructed with public resource. However, as the edge was not built, many people did not leave the place of the ancient housing and they rebuilt their homes and/or trade in the same place. According to Silva et al. (2003) flood events (flood history) in Pernambuco are recurrent as shown in the following daily averages presented in Table 2 .

Table 2: Historical data of extreme events in Palmares. Source: Adapted from of CPRM (2014)

\begin{tabular}{cc}
\hline Year & Rainfall $\left(\mathrm{mm}^{3}\right)$ \\
\hline 1973 & 110.0 \\
1975 & 940.0 \\
1988 & 459.0 \\
2000 & Estimated 1200.0 \\
2010 & 170.0 \\
2011 & 209.0 \\
2017 & 114.0 \\
\hline
\end{tabular}

However, effective measures must be implemented by public power and communitysupported to prevent possible disasters in periods of extreme events. The Figures 7 and 8 show the geomorphology characterization and the DTM, respectively.

From the RapidEye images it was possible to observe the Una River bordering to the city's whole urban area, by overlapping to the floods susceptibility map data it was verified that to the flood risk area is high and medium and this is densely populated. It is worth highlighting that the BR-101, bridge and edge are in areas classified with high flood risk as shown in Figures 9 and 10. 


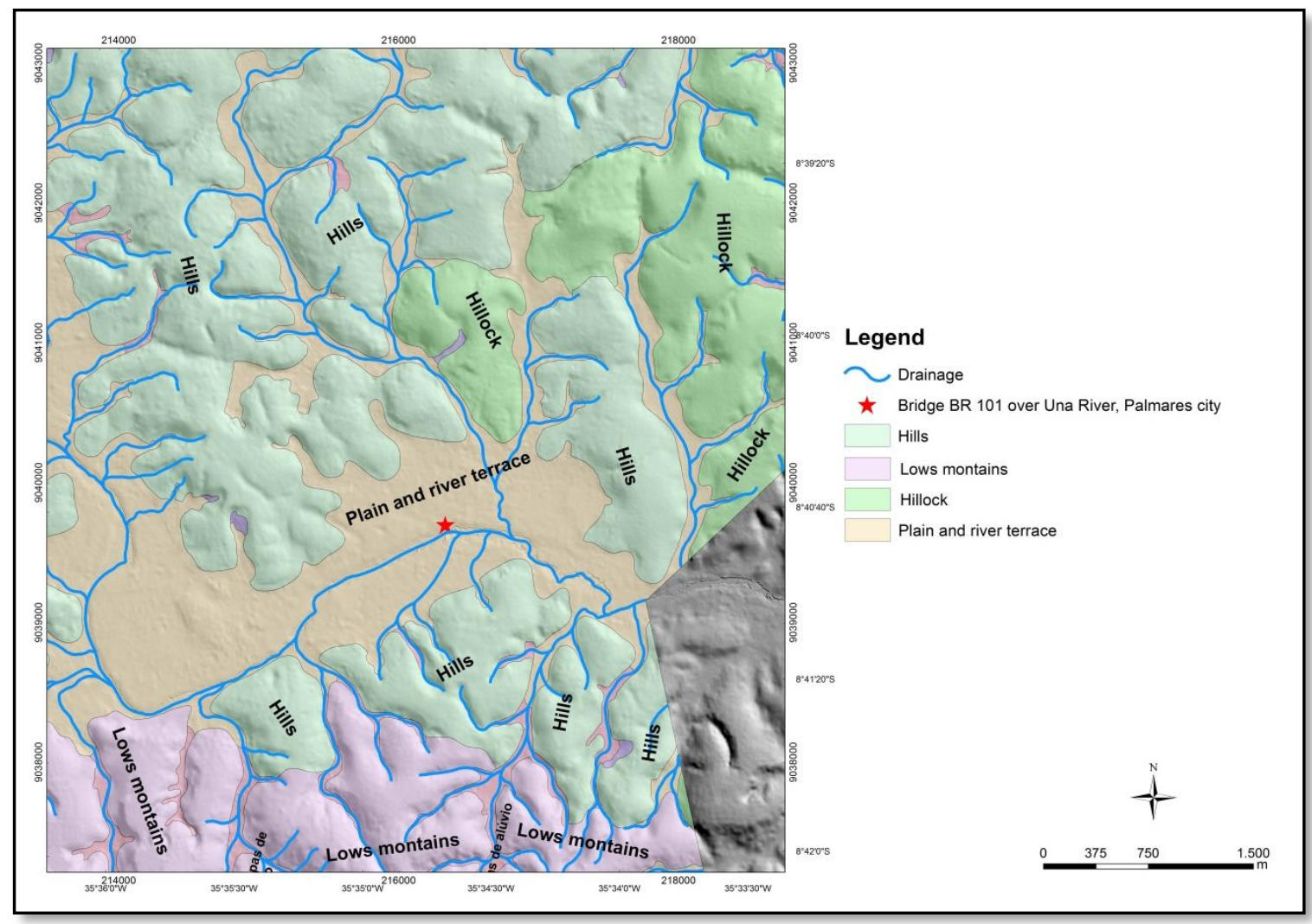

Figure 7: Area's geomorphology characterization. Source: Adapted from CPRM (2016)

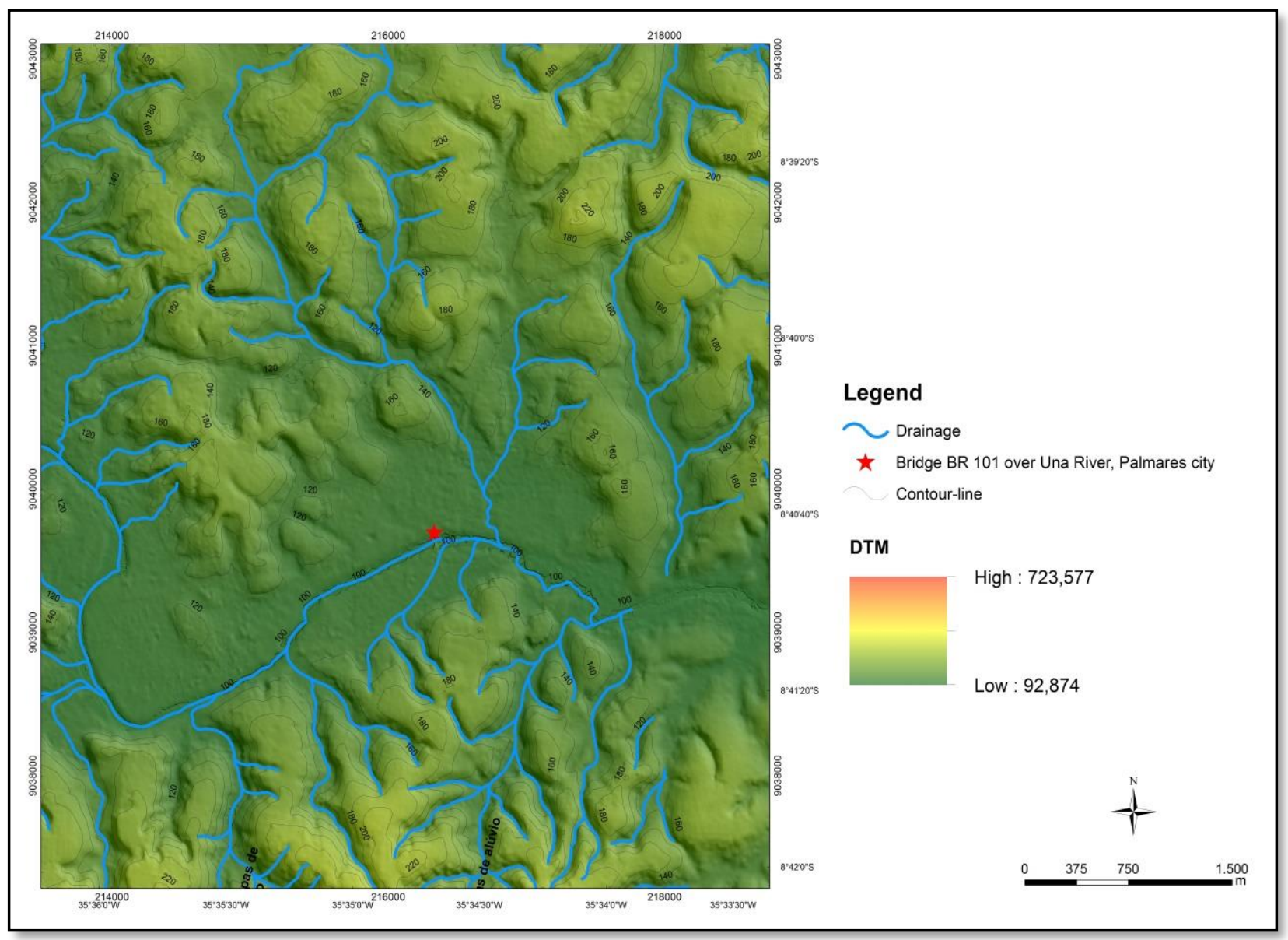

Figure 8: Area's DTM. Source: Adapted from CPRM (2016) 
As shown in Figure 7, the geomorphology of the city's urban area is formed by several hillock, lows mountains and hills with height of the top ranging from $120 \mathrm{~m}$ to $220 \mathrm{~m}$ (as shown in Figure 8). Also, in the figures can be seen, the BR-101 margins the river, the visited point and great part of the city's urban area, it is located in a plains and fluvial terraces, with altitude of $100 \mathrm{~m}$ above the sea level, what facilitates the water spreading in situation of great rainfall index and the higher height areas together with the anthropic actions serve as a dam for the containment of the fluvial water, avoiding the waters drainage, consequently provoking floods with greater intensity.

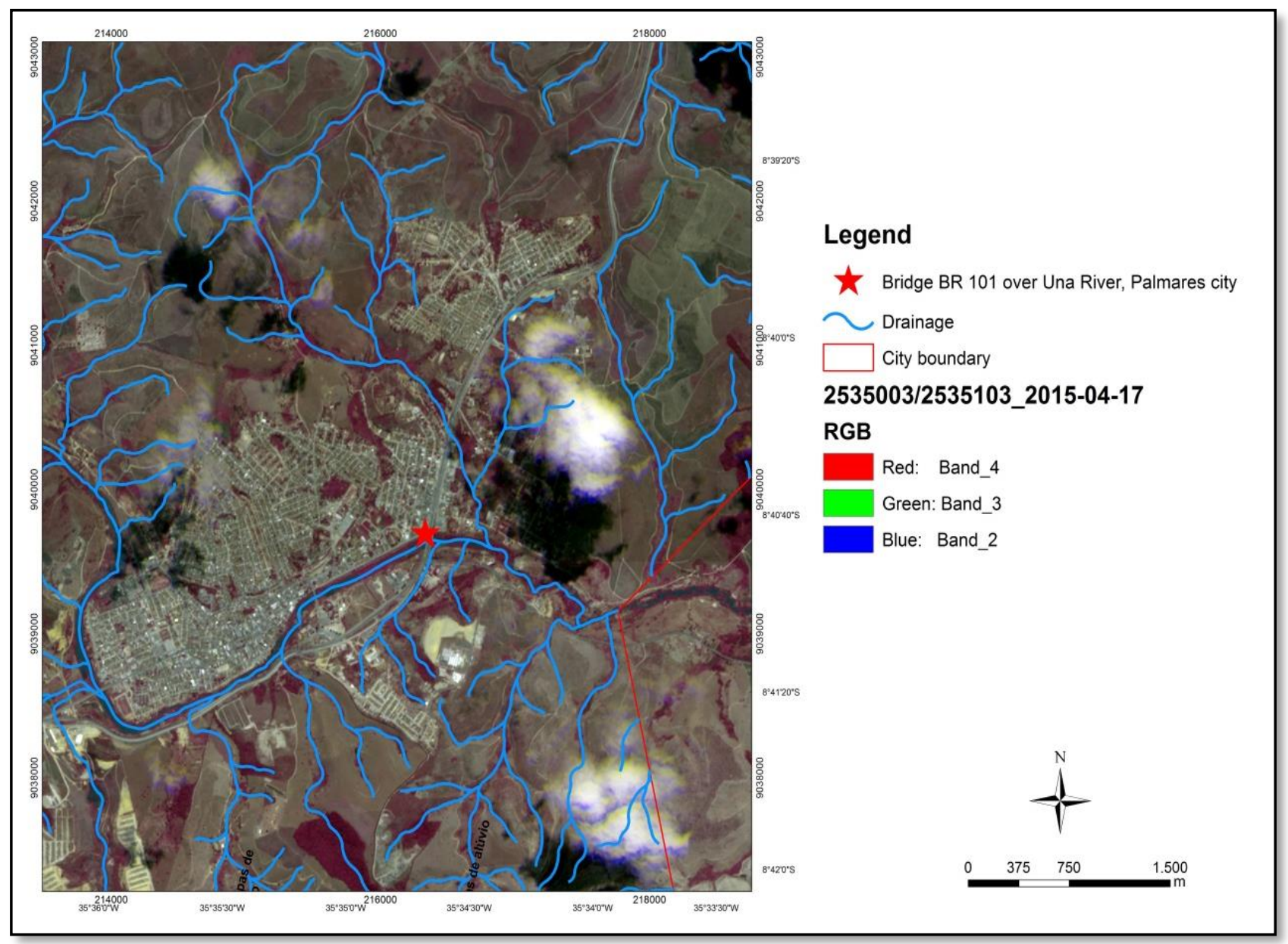

Figure 9: Clipping of area's RapidEye satellite image with the identification anthropic features. 


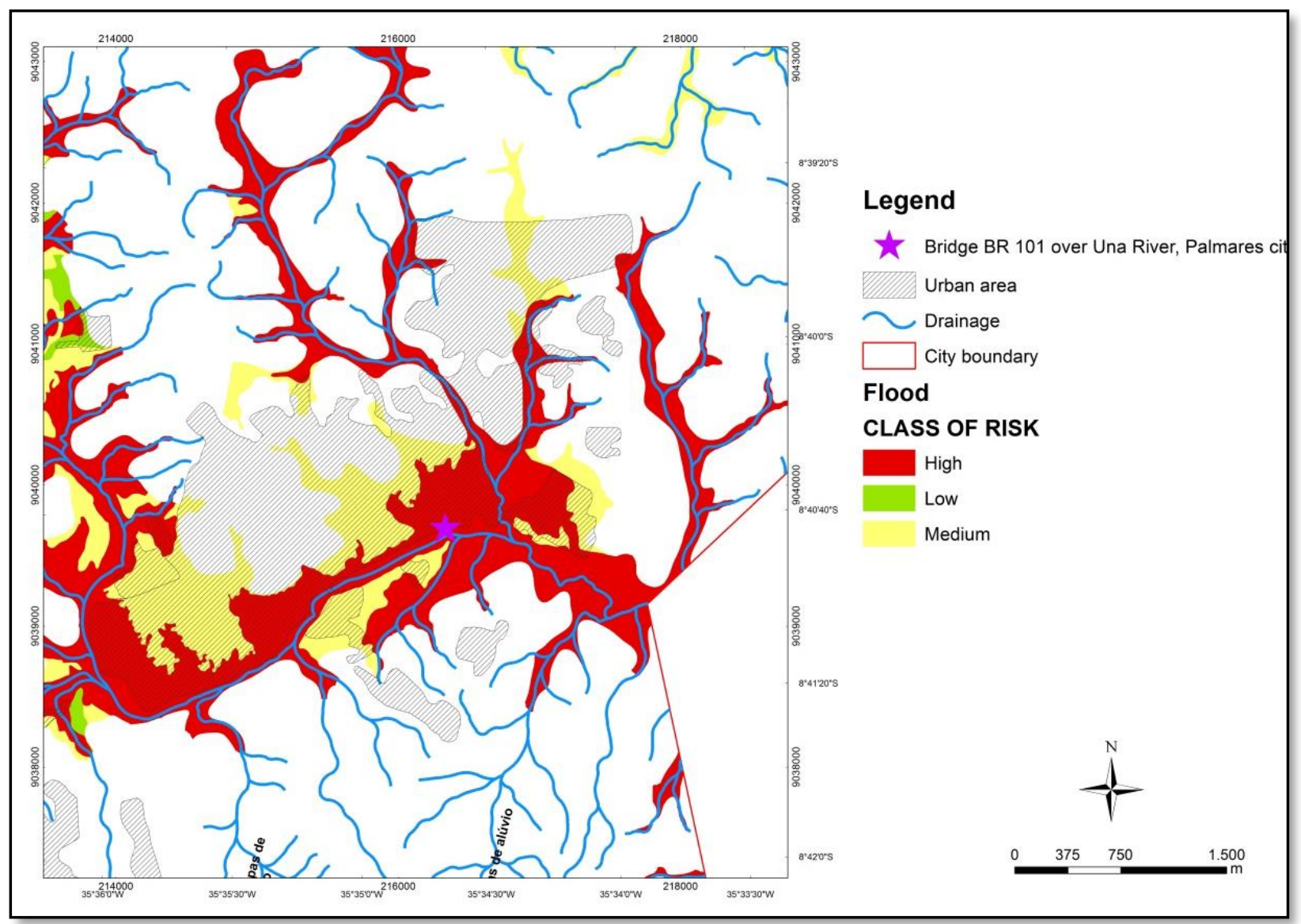

Figure 10: Clipping of Flood Susceptibility Map.

As shown in Figure 9, the area's satellite image clipping with the identification of the anthropic features, it was essential for overlap in the Flood Susceptibility Map (Figure 10) being highlighted the identified features in the satellite image clipping. With the maps and the rainfall indexes presented, there is a great concern with the residents who lives in Palmares, since many of this residents, they was affected by the floods of 2000 and 2011. But even so they rebuilt their houses and trade, in areas of plains and fluvial terraces. It is noteworthy that the residents that lived nearby or in the area where the edge was built they were relocated by the public power to the areas classified by geomorphology as low mountain and hills.

The event occurred between June 16 and 19, 2010, according to Girão et al. 2013, at Zona da Mata South of the State of Pernambuco, but with greater intensity in the Una and Serinhaém river basins, are examples of the atmospheric and rainfall characteristic. The atmospheric circulation normal patterns on a large-scale determine the month of June as one of the greatest precipitation months of the rainy season in the coastal strip of Pernambuco. When atmospheric oceanic anomalies occur, this pattern can influence the amount of rainfall for more or less. During this period, there was the confluence of the two atmospheric systems acting integrated with the occurrence of two important anomalies on the oceans. These factors contributed to the greater intensity and permanence of the extreme event. It is worth noting that in pertaining to the flood of 2010, Una River rose $12 \mathrm{~m}$ in relation to its normal bed. This flood caused calamity to the city, where even the residents that lived in second floor were affected by the waters (CPRM, 2014).

The flat areas of the slopes are wide and with less than $3^{\circ}$ inclination, but the aridity of the soils favor the precipitation regimes surface runoff. In this area, laminar erosive features occur with low degree of susceptibility to the mass gravitational movement. It highlight that in relation to the mass gravitational movements, $89.461 \%$ of the urbanized and built area, is classified as low risk class, while that to the floods susceptibility cover $18.939 \%$ of the area, being classified as high risk class, according to CPRM (2014).

With the construction of the Serro Azul Dam, final phase, there is a prospect by the riverside population that there is no possibility of another such event, as happened in 2011. This 
assertion was ratified with the event that occurred in May 2017, with more than $100 \mathrm{~mm}$ of rainfall and without many damages. Generally, when rainfall indexes reached this value, the event was catastrophic for the population, but as the Serro Azul Dam contained upstream water, the event had less destructive power.

Focusing on resilience, when before the disaster, Palmares Civil Defense only existed on paper. According to Oliveira (2015), Civil Defense is now a reference in the Mata South, being the first city in the Northeast to be certified by the United Nations in the Resilient Cities campaign, which aims to strengthen the role of local governments in the commitment around sustainable development practices that reduce disaster risks and reduce vulnerabilities.

It is observed that some guidelines were created or established in the city after the disasters of 2010 and 2011, such as Civil Defense having a more active role in risk areas with actions jointly with the community; the construction of Serro Azul Dam was a milestone for new disasters not to occur with the intense rains of 2017. However, building homes for residents outside the risk areas is still a project that needs more attention.

\section{Conclusion}

There is a need to raise awareness the population not to occupy risk areas because the flood period is cyclical and the city is flat, contributing to flooding since the river's main bed is silted and occupied by constructions along its banks.

The main impacts related to the floods in Palmares are associated to lack of urban planning, absence of basic infrastructure, without land use control, flood warning system. Studies such as the Geotechnical Map and the pluviometers implementation already in the elaboration process will contribute to the city in the deployment decision of new ventures. The main challenge is to develop an effective method that incorporates risk perception into existing vulnerability to adaptation and resilience mechanisms, enhancing planning and governance actions through nonlinear visions that consider the processes dynamics, uncertainties and possible unforeseen events.

The high-resolution satellite images contribute to the monitoring and verification of the current situation of the areas affected by the floods, and it is possible to make temporal studies. These data integrated to the flood mapping are tools that allow public managers to better urban occupation plan, avoiding new disasters.

\section{Acknowledgments}

The authors would like to thank to Environment Ministry for providing free of charge in the Geocatálogo the RapidEye highresolution satellite images.

\section{References}

Amaral, R., Ribeiro, R.R., 2009. Desastres naturais conhecer para prevenir: Inundações e Enchentes. São Paulo: Instituto Geológico.

Araujo, R.A., 2010. A cidade sou eu. Paper final:Pluris, 1-10.

Bandeira, A.P.N., Coutinho, R.Q., 2008. Gerenciamento de Risco de Escorregamentos de Encostas na Região Metropolitana do Recife-PE. COBRAMSEG.

Bandeira, A.P.N, Coutinho, R.Q., Alheiros, M.M., 2009. Importância da Caracterização Geológico-Geotécnica e da Chuva para Gerenciamento de Áreas de Riscos, 1-10.

CPRM Serviço Geológico do Brasil, 2014. Mapa de Suscetibilidade. Recife. http://www.brasil.gov.br/observatoriodaschuv as/mapeamento/mapa-suscetibilidade. $\mathrm{html}$. (Accessed 15 August 2016)

CPRM Serviço Geológico do Brasil, 2016. Cartas de Susceptibilidade a Movimentos Gravitacionais de Massa e Inundações. http://www.cprm.gov.br/publique/GestaoTerritorial/Geologia-de-Engenharia-eRiscos-Geologicos/Cartas-de-Suscetibilidadea-Movimentos-Gravitacionais-de-Massa-eInundacoes-3507.html. (Accessed 16 September, 2016)

Cunico, C., Oka-Fiori, C., 2014. O estado de normalidade e o estado de exceção diante da importância das categorias de "Vulnerabilidade", "Risco" e "Resiliência". Caminhos de Geografia - Revista online, ISSN 1678-6343, 15 (52), 01-20.

Girão, O.S., Corrêa, A.C.B., Nobrega, R.S., Duarte, C.C., 2013. O papel do clima nos estudos de prevenção e diagnóstico de riscos geomorfológicos em bacias hidrográficas na Zona da Mata Sul de Pernambuco. In: Antonio José Teixeira Guerra; Maria do Carmo Oliveira Jorge. (Org.). Processos Erosivos e Recuperação de Áreas Degradadas. 1ed. São Paulo: Oficina de Textos, 126-159. 
Gonçalves, R.M., Pacheco, A.P., Tanajura, E.L.X., Da Silva, L.M., 2013. Urbanização costeira e sombreamento na praia de Boa Viagem, Recife-PE, Brasil. Revista de Geografia Norte Grande, ISSN 0718- 3402, 54, 241-255, 2013. http://dx.doi.org/10. 4067/S0718-34022013000100013.

IBGE (Instituto Brasileiro de Geografia e Estatística), 2010. Censo Demográfico 2010. http://www.censo2010.ibge.gov.br. (Accessed 13 August, 2017)

IBGE (Instituto Brasileiro de Geografia e Estatística), 2017. Mapa de distribuição da população 2000 , http://www.ibge.gov.br/home/geociencias/ge ografia/mapas_doc1. shtm. (Accessed 06 September, 2017)

ITEP (Instituto de Tecnologia de Pernambuco), 2011. Relatório de impacto ambiental: estudo de impacto ambiental - EIA: sistema de controle de cheias da bacia do rio Una Barragem Serro Azul. Recife: ITEP/Unidade Gestora de Projetos Barragens da Mata Sul, 41 p.

MMA (Ministério do Meio Ambiente), 2016. Geocatálogo, <http://geocatalogo.mma. gov.br/>. (Accessed 16 October, 2016)

Novack, T., Kux, H.J.H., 2010. Urban land cover and land use classification of an informal settlement area using the open-source knowledge-based system InterIMAGE. Journal of Spatial Science, 23-41.

Oliveira, E.M., 2013. Análise das políticas de gestão dos recursos hídricos e seus reflexos sobre as enchentes provocados pelo Rio Una em Palmares-PE. Dissertação (Mestrado em Tecnologia Ambiental) - Instituto de Tecnologia de Pernambuco, Recife.

Oliveira, J. P. Q., 2015. Palmares resiliente: a Reconstrução do Urbano após as enchentes de 2010/11. Dissertação (Mestrado em Administração) - Universidade Federal de Pernambuco.

RapidEye, 2016 Delivering the World - Satellite Imagery Product Specifications. http://www2.flyby.it/images/brochure/rapidey
e/eng/RE_Product_Specifications_ENG.pdf. (Accessed 15 September, 2016)

Reckziegel, B.W., Robaina, L.E.S., 2005. Riscos geológico-geomorfológicos: revisão conceitual. Ciência e Natura 27, 65-83.

Sánchez, R., 2010. La debilidad de la gestión del riesgo enlos centros urbanos. El caso del Área Metropolitana de Santiago de Chile. Revista de Geografía Norte Grande 47 (5-26).

Santos, J.C., Toujaguez, R., Silva, B.Q., Da Silva, L.M., 2016. Atualização do Mapeamento de Risco Geológico do Bairro Mutange no Município de Maceió-AL, Brasil. Libro de Actas del XVII Simposio Internacional em Percepción Remota y Sistemas de Información Geográfica: Geotecnologías, herramientas para la construcción de una nueva visión del cambio global y su transformación para um futuro sostenible 17, 291-303.

Silva, S.R., Freire, P.K.C., Barbosa, D.L., Wanderley, S.F.S., 2003. A gestão dos recursos hídricos em Pernambuco. In: Simpósio Brasileiro de Recursos Hídricos, 15, Curitiba. Anais, Porto Alegre: ABRH, 499.

Silva, B.Q., Da Silva, L.M., Schuler, C.A.B., 2017. Utilização de imagens do satélite de alta resolução RapidEye para análise da resiliência da população as margens do rio Una, Palmares, Pernambuco, Brasil. Anais do XVIII Simpósio Brasileiro de Sensoriamento Remoto, ISBN: 978-85-17-00088-1, 27842791.

SNIRH (Sistema Nacional de Informação em Recursos Hídricos), 2016. Informações sobre recursos hídricos. http://www.snirh.gov.br/. (Accessed 28 September, 2017)

Tominaga, L.K., 2009. Desastres naturais conhecer para prevenir: Escorregamento. São Paulo: Instituto Geológico. http://www.igeologico.sp.gov.br/downloads/li vros/ DesastresNaturais.pdf. (Accessed 16 July, 2017)

Tominaga, L. K., Santoro, J., Amaral, R., 2015. Desastres Naturais: conhecer para prevenir. São Paulo: Instituto Geológico. 